\title{
F-Box Only Protein 32
}

National Cancer Institute

\section{Source}

National Cancer Institute. F-Box Only Protein 32. NCI Thesaurus. Code C104225.

F-box only protein 32 ( $355 \mathrm{aa}, \sim 42 \mathrm{kDa}$ ) is encoded by the human FBXO32 gene. This protein plays a role in protein ubiquitination and degradation. 